\title{
Role of probiotics in lower reproductive tract infection in women of age group 18 to 45 years
}

\section{Rukshana Shamshu*, Jayasree Vaman, Nirmala C.}

Department of Obstetrics and Gynaecology, Government Medical College, Thiruvananthapuram, Kerala, India

Received: 10 December 2016

Accepted: 05 January 2017

\section{*Correspondence:}

Dr. Rukshana Shamshu,

E-mail: rukshanaimtyaz@gmail.com

Copyright: $\odot$ the author(s), publisher and licensee Medip Academy. This is an open-access article distributed under the terms of the Creative Commons Attribution Non-Commercial License, which permits unrestricted non-commercial use, distribution, and reproduction in any medium, provided the original work is properly cited.

\section{ABSTRACT}

Background: This study has been designed to assess the effectiveness of the probiotic strains having Lactobacillus rhamnosus GR-1 and Lactobacillus reuteri RC-14 in the management of lower genital infections (bacterial vaginosis and candidiasis) as an integral therapy with antibiotics.

Methods: Double blind, randomized placebo controlled study in women between 18-45 years attending Sree Avittom Thirunal Hospital (SATH), Government Medical College, Thiruvananthapuram, India with symptoms of bacterial vaginosis and vulvovaginal candidiasis. Women giving consent were given probiotics along with conventional antibiotics and were followed up over a period of two months. Outcome is measured as percentage of women showing a score of less than 4 at the end of thirty days of treatment, and sixty days of treatment in the test and control group in the case of bacterial vaginosis and no discharge and absence of hyphae and pseudohyphae in wet smear and gram stain in case of candidiasis.

Results: Out of 42 women studied, 32 had bacterial vaginosis and 10 had vulvovaginal candidiasis. $81.3 \%$ women with BV had a normal vaginal picture after sixty days of treatment as compared to placebo which was only $31.3 \%$. The $\mathrm{p}$ value is 0.004 which is significant. In the treatment of $\mathrm{VC}$, the percentage of women cured was the same in both probiotic and placebo group.

Conclusions: In the treatment of bacterial vaginosis, addition of probiotics to the conventional antibiotics can improve the cure rate of bacterial vaginosis and reduce the rate of recurrences. In the treatment of vulvovaginal candidiasis, addition of probiotics to the conventional antifungal did not have a significant improvement.

Keywords: Bacterial vaginosis, Genital infections, Probiotic, Vulvovaginal candidiasis

\section{INTRODUCTION}

One of the most common reasons a woman visits a medical practitioner is urogenital infection. One billion women around the world suffer from non-sexually transmitted urogenital infections such as bacterial vaginosis, urinary tract infection and yeast vaginitis.

A healthy woman has a urogenital micro flora which comprises more than fifty species of organisms whose composition differs according to the reproductive stages and exposure to several factors. When a woman is healthy the vagina contains indigenous organisms and at the time of infection the infecting pathogens dominate the urogenital flora. Lacto bacilli is seen in the flora of premenopausal women and they have properties like adhesive ability, production of acids, bacteriocins, hydrogen peroxide and they give protection to the host. ${ }^{1}$

Vulvovaginal candidiasis is a common infection among women and studies show that 6.5 to $8.0 \%$ of women older than 18 years have more than one episode of Vulvovaginal candidiasis in their life time. Probiotics may be considered as potential preventive agents in women who have many episodes of Vulvovaginal candidiasis, however studies conducted so far are 
inconclusive regarding the beneficial effects of probiotics in treatment of Vulvovaginal candidiasis. ${ }^{2}$ Symptomatic vulvovaginal candidiasis is defined as symptoms (vaginal itch or irritation with or without discharge) plus candida isolated from the follow up vaginal swab. Bacterial vaginosis is a major cause of urogenital disease in females. It is a mild infection of the lower female genital tract and need three out of four criteria which includes:

- Release of an amine (Putresine, cadaverine and trimethyl amine) or fishy odour after adding $10 \%$ potassium hydroxide.

- A vaginal $\mathrm{pH}$ more than 4.5

- Clue cells in the vaginal fluid, and

- A milky homogenous vaginal discharge.

The clue cells scoring of the cell population can be

- $\quad$ Normal (0-3; dominated by lactobacilli rods),

- Intermediate (4-6; colonisation by small gram negative or gram variable rods like Bacteroides or Gardnerella, and curved gram variable rods like Mobiluncus) or

- $\quad$ Bacterial vaginosis (7-10; dominated by pathogens)

Bacterial vaginosis has been strongly associated with adverse pregnancy outcomes such as preterm birth, chorioamnionitis, post abortion and postpartum pelvic infection. There have also been studies which show a strong association with HIV and other STD transmission among women with bacterial vaginosis. In SAT Hospital, Medical College, Thiruvananthapuram, 40-50\% of women attending the gynaecology OPD present with vaginal discharge.

It has been found in a study conducted at SATH that the prevalence of bacterial vaginosis in women between 18 to 45 years is $19.3 \%$. The polymicrobial nature of BV is a problem to clinicians in finding the most appropriate drug therapy. Currently treatment recommendations worldwide advocate that BV may be treated with either metronidazole or clindamycin. These regimes have a high risk of antibiotic resistance, adverse effects and recurrences.

This concept of restoring the lactobacillus content of the vaginal microflora so that infection can be prevented was first conceived by Andrew Bruce in the beginning of the seventies. Research since then has shown that certain lactobacillus strains can colonise the vagina and reduce the risk of lower reproductive tract infections.

Recently studies have stressed on the importance of a healthy, lactobacilli dominated flora in the urogenital tract not only to prevent sexually transmitted disease and preterm labour but also to maintain the quality of life of women. Studies across the world have shown a protective role for lactobacilli in lower reproductive tract infection in women. Such a study has not been done at SATH where $40 \%$ women present with vaginal discharge. Hence this study has been designed.

\section{Rationale of the study}

In the gynaecology OPD of SATH, 40 to $50 \%$ women present with vaginal discharge. $24.7 \%$ of them have a flora suggestive of bacterial vaginosis. Vulvovaginal candidiasis has a high incidence of recurrence and each episode significantly affects the quality of life of a woman. Incidence of HIV and STDs are on an increase. Bacterial vaginosis has been found to be associated with preterm labour, PROM, postpartum endometritis, puerperal and post abortion sepsis which can be prevented by early treatment. It is also associated with post-operative infections and vaginal cuff cellulitis.

To avoid the rising rates of antibiotic resistance, following use in lower reproductive tract infection the role of probiotics has been considered as a means of protection against lower reproductive tract infection. Probiotics have been tested for their effectiveness and safety and have completed animal studies, phase two, three and four trials. There are reports stating the effectiveness of probiotics in various infections including genitourinary infections. In present population, there is a large number of women in the reproductive age group with genital tract infections as well as recurrent infections. Hence the significance of this study to evaluate the role of probiotics in lower reproductive tract infections in our institution. In view of the above factors, this study has been considered.

\section{Objectives}

\section{Primary objective}

To assess the effectiveness of the probiotic strains having Lactobacillus rhamnosus GR-1 and Lactobacillus reuteri RC-14 in the management of lower genital infections (bacterial vaginosis and candidiasis) as an integral therapy with antibiotics.

\section{Secondary objective}

To assess the effectiveness of the probiotics in maintaining a healthy genital flora throughout the treatment period.

The parameters used to evaluate the patients were vaginal $\mathrm{pH}$, vaginal wet smear, gram stain at initial visit, after thirty days of treatment and after sixty days of treatment.

\section{METHODS}

The study was double blind, randomized placebo controlled study which was conducted at Department of Obstetrics and Gynaecology, Sree Avittom Thirunal Hospital (SATH), Government Medical College, Thiruvananthapuram, Kerala, India for 1 year. Study 
population was women attending the outpatient department of gynaecology in SATH, Government Medical College, Thiruvananthapuram, India.

Sampling technique is Randomization. Randomization sequence will be electronically generated by an independent statistician. Combinations used AABB, $\mathrm{ABAB}, \mathrm{ABBA}, \mathrm{BABA}, \mathrm{BAAB}, \mathrm{BBAB}$ where $\mathrm{A}$ and $\mathrm{B}$ are either probiotic or placebo.

Formula used and sample size

$$
n=\frac{(\mathrm{Z} \alpha+\mathrm{Zz} \beta)^{2}\left\{\pi_{1}\left(1-\pi_{1}\right)+\pi 2\left(1-\pi_{2}\right)\right\}}{\delta^{2}}
$$

Where $\alpha=$ Type I error (fixed at $5 \%$ level); $1-\beta=$ Power (fixed at $80 \%$ level); $\pi_{1}=$ Control group response; $\pi_{2}=$ Study group response; $\delta=\pi_{1}-\pi_{2}$.

Applying the formula, sample size is 42, of which 21 study group and 21 control group.

\section{Inclusion criteria}

- Patients attending gynaecology outpatient department with vaginal discharge.

- Women aged 18 to 45 years

- Willing to give consent

\section{Exclusion criteria}

- Pregnant or lactating women

- History of Probiotic, Synbiotic administration in the past one month.

- Patients with known hypersensitivity for Probiotics / Synbiotics

- Patients with chronic or severe respiratory, cardiovascular, CNS, Endocrine and other gastrointestinal disorders

\section{Tool}

Women between 18-45 years attending SATH OPD with symptoms of lower reproductive tract infection (specifically bacterial vaginosis and candidiasis ) giving consent will be included in the study. After giving written informed consent, a standardized questionnaire is given to be filled up. A general examination followed by local examination will be done.

Vaginal pH will be assessed by a graded litmus paper applied to the vaginal secretions obtained by placing a sample from the lateral wall of the vagina on $\mathrm{pH}$ paper. The paper has a range of $\mathrm{pH}$ from 4.0 to above 5.0. The normal $\mathrm{pH}$ is 4.5 or less. The $\mathrm{pH}$ is assessed by the colour change of the $\mathrm{pH}$ strip compared to the scale given along with the $\mathrm{pH}$ kit. Alkaline $\mathrm{pH}$ will be seen as a blue or green colour and acidic $\mathrm{pH}$ will show an orange colour. A vaginal smear will be taken with two cotton tipped sterile swabs for a wet film examination and for a gram stained smear. The sampling is done with the patient in lithotomy position. A speculum is used to facilitate use of a swab to sample fluid inside the vagina. The sample is then smeared upon a microscope slide and is observed by wet mount microscopy by placing the specimen on a glass slide and mixing with a salt solution. Bacterial vaginosis generally produces a vaginal discharge that is thin and milky with a fishy odor. Bacterial vaginosis is suspected if the vaginal $\mathrm{pH}$ is alkaline and the wet smear shows the presence of clue cells.

Candidiasis is suspected if the discharge is thick, has a normal $\mathrm{pH}$ and smear shows hyphae or pseudo hyphae.Next randomization will be done. Besides the patient, the primary investigator, the research nurses allocating and distributing the drug and the evaluator are to be blinded to the randomization process. The probiotic used in the study contains two Lactobacilli strains (Lactobacillus rhamnosus GR-1 and Lactobacillus reuteri RC-14) developed and studied by Reid et al, oral capsules containing more than one million bacilli of each strain. The placebo used contains methyl cellulose. To one group, the usual regime of management of lower reproductive tract infection will be given. (Tab Metronidazole $400 \mathrm{mg}$ 1-0-1 for 7 days) and Drug A will be given along with the standard regime for 60 days; two capsules per day for thirty days and one capsule per day for the next thirty days.

To the other group, drug B will be given along with the standard regime for sixty days; two capsules per day for the 30 days and then one capsule per day for the next thirty days. A cervicovaginal smear taken and Nugent's scoring will be done for all the patients at the time of presentation, and then at day 30 and day 60 .

\section{Nugent's score}

In this scale, a score of $0-10$ is generated from combining three other scores. 0-3 is considered negative for BV; 4-6 is considered; $7+$ is considered indicative of $\mathrm{BV}$. At least 10 -20 high power $(1000 *$ oil immersion) fields are counted and an average determined.

Table 1: Nugent's score.

\begin{tabular}{|c|c|c|}
\hline $\begin{array}{l}\text { Lactobacillus } \\
\text { morphotypes }\end{array}$ & $\begin{array}{l}\text { Gardnerella/ } \\
\text { Bacteroides } \\
\text { morphotypes }\end{array}$ & $\begin{array}{l}\text { Curved gram } \\
\text { variable rods }\end{array}$ \\
\hline Score 0 for $>30$ & Score 0 for 0 & Score 0 for 0 \\
\hline Score 1 for $15-30$ & Score 1 for $<1$ & Score 1 for $<5$ \\
\hline Score 2 for $1-14$ & Score 2 for $1-4$ & Score 2 for $5+$ \\
\hline
\end{tabular}

Outcome will be measured as percentage of women showing: a score of less than 4 at the end of thirty days of treatment, and sixty days of treatment in the test and control group in the case of bacterial vaginosis and No discharge and absence of hyphae and pseudohyphae in wet smear and gram stain in case of candidiasis. 


\section{Ethical concerns}

- Ethical clearance from the institutional ethics committee.

- Informed written consent

- Clinical trials registry of India registration.

\section{Data analysis}

Data were entered in Excel sheet and analysis done by using SPSS Software version 17.

Qualitative variables described by percentage distribution and quantitative variables described by mean standard deviation, minimum and maximum. Between groups comparison of quantitative variables analysed by Chi square test, before and after comparison of qualitative variable was analysed by Mc Nemar test.

$\mathrm{P}$ value less than 0.5 was taken as significant. Randomized, double blind, placebo controlled study of probiotics in women with lower reproductive tract infection.

\section{RESULTS}

42 women attending gynaecology OPD with complaints of vaginal discharge giving informed consent participated in the study. They were allocated to either of two groups A or B according to a random table. The infections studied were Bacterial vaginosis and vulvovaginal candidiasis. 32 women had bacterial vaginosis and 10 women had vulvovaginal candidiasis.

\section{Baseline characteristics of the study population}

Distribution of study population between age groups

$50 \%$ of women in the study population were between 26 to 35 years, $35.7 \%$ women were in the age group of 36 to 45 years and $14.2 \%$ women were between 18 to 25 years.

\section{Distribution of study population based on domicile}

$59.5 \%$ women who participated in the study lived in a rural area, while $40.4 \%$ women lived in an urban area.

\section{Distribution of study population according to religion}

$61.9 \%$ women were Hindus, $23.8 \%$ women were Christians and $14.2 \%$ women were Muslims.

Distribution of study population based on employment status

$71.4 \%$ women in the study group were unemployed while $28.5 \%$ women were employed.
Distribution of study population according to monthly income

$59.5 \%$ had a monthly income less than Rupees 500, 30.9 $\%$ women had an income between Rupees 501 to 1600 and 9.5\% women had an income more than Rupees 1601 .

Distribution of study population according to educational status

$45.2 \%$ of women in the study population were having education below 10th standard, while $54.8 \%$ of women were having an education below $10^{\text {th }}$ standard.

Distribution of study population according to age at menarche

$52.3 \%$ of women had their menarche between 14 and 16 years, while $33 \%$ of the women had their menarche before 13 years.

Distribution of study population according to regularity of menstrual cycles

$80.9 \%$ of the women had regular menstrual cycles, while $19.1 \%$ women had irregular cycles.

Distribution of study population according to history of prior treatment for vaginal discharge

42.9\% women had taken prior treatment for vaginal discharge.

Distribution of study population according to duration of married life

$9 \%$ of women were married less than 5 years, $57 \%$ were married between 5 and 10 years, and $33 \%$ were married more than 11 years.

Distribution of study population according to contraceptive practices

$45 \%$ women did not use any form of contraception, 9.5

$\%$ used a barrier method, 11. $9 \%$ used an IUCD and 33

$\%$ had undergone postpartum sterilisation.

\section{Detailed study}

\section{Bacterial vaginosis}

There were 42 women in the study population. 32 women had bacterial vaginosis. The initial vaginal $\mathrm{pH}$ at the first visit was alkaline which was more than 4.5 for all 32 women. The initial wet smear was suggestive of bacterial vaginosis. The initial gram stain also showed bacterial vaginosis. These 32 women were then randomised to 2 groups A or B. There were 16 women in each group. 
Change in $\mathrm{pH}$ from day 0 to day 30

In group $\mathrm{A}$, from the initial 16 women with an abnormal $\mathrm{pH} ; 13$ women had a normal $\mathrm{pH}$ at the end of thirty days of treatment. $(81.3 \%)$; In group $\mathrm{B}$, from the initial 16 women with an abnormal vaginal $\mathrm{pH} ; 5$ women had a normal vaginal $\mathrm{pH}$ at the end of thirty days of treatment. $(31.3 \%)$. The $\mathrm{p}$ value is 0.004 which is significant (Table 2).

Change in wet smear and gram stain after thirty days of treatment

In group A, 13 women out of the initial 16 had a normal gram stain and wet smear after 30 days of treatment. In group B, 5 women out of the initial 16 had a normal gram stain and wet smear at the end of treatment. The $\mathrm{p}$ value is 0.004 which is significant (Table 3).
Table 2: Bacterial vaginosis - change in $\mathrm{pH}$ from day 0 to day 30 .

\begin{tabular}{|c|c|c|c|c|}
\hline & \multicolumn{2}{|c|}{$\begin{array}{l}\text { Group A, after } 30 \\
\text { days }\end{array}$} & \multicolumn{2}{|c|}{$\begin{array}{l}\text { Group B, after } 30 \\
\text { days }\end{array}$} \\
\hline $\begin{array}{l}\text { Change in } \\
\mathrm{pH} \text { from } \\
\text { day } 0 \text { to } \\
\text { day } 30\end{array}$ & Frequency & Percent & Frequency & Percent \\
\hline $\begin{array}{l}\text { Normal } \\
\mathrm{Ph}\end{array}$ & 13 & $81.3 \%$ & 5 & $31.3 \%$ \\
\hline $\begin{array}{l}\text { Abnormal } \\
\mathrm{pH}\end{array}$ & 3 & $18.8 \%$ & 11 & $68.8 \%$ \\
\hline Total & 16 & $100 \%$ & 16 & $100 \%$ \\
\hline
\end{tabular}

Table 3: Bacterial Vaginosis - Change in wet smear and gram stain after thirty days of treatment.

\begin{tabular}{|l|l|l|l|l|}
\hline $\begin{array}{l}\text { Change in wet smear and gram stain after thirty days } \\
\text { of treatment }\end{array}$ & Group A & Gercent & Frequency & Percent \\
\hline Normal & Frequency & $81.3 \%$ & 5 & $31.3 \%$ \\
\hline Bacterial vaginosis & 13 & $18.8 \%$ & 11 & $68.8 \%$ \\
\hline Total & 3 & $100 \%$ & 16 & $100 \%$ \\
\hline$\chi 2=8.127 \mathrm{df}=1 \mathrm{p}=0.004$ & 16 & & & \\
\hline
\end{tabular}

\section{Change in $\mathrm{pH}$ from day 0 to day 60}

In group $\mathrm{A}$, from the initial 16 women with an abnormal $\mathrm{pH} ; 13$ women had a normal $\mathrm{pH}$ at the end of 60 days of treatment. In group B, from the initial 16 women with an abnormal vaginal $\mathrm{pH} ; 5$ women had an abnormal vaginal $\mathrm{pH}$ at the end of 60 days of treatment. The $\mathrm{p}$ value is 0.004 which is significant (Table 4).

Table 4: Bacterial Vaginosis - Change in pH from day 0 to day 60.

\begin{tabular}{|l|l|l|l|l|}
\hline Change in $\mathrm{pH}$ from day 0 to day 60 & Frequency & Percent & Frequency & Percent \\
\hline Normal $\mathrm{pH}$ & 13 & $81.3 \%$ & 5 & $31.3 \%$ \\
\hline Abnormal $\mathrm{pH}$ & 3 & $18.8 \%$ & 11 & $68.8 \%$ \\
\hline Total & 16 & $100 \%$ & 16 & $100 \%$ \\
\hline$\chi 2=8.127 \mathrm{df}=1 \mathrm{p}=0.004$ & & & & \\
\hline
\end{tabular}

Table 5: Bacterial Vaginosis - Change in wet smear and gram stain after sixty days of treatment.

\begin{tabular}{|l|l|l|l|l|}
\hline $\begin{array}{l}\text { Change in wet smear and gram stain after sixty } \\
\text { days of treatment }\end{array}$ & Group A & \multicolumn{3}{c|}{ Group B } \\
\hline Cured & Frequency & Percent & Frequency & Percent \\
\hline Not cured & 13 & $81.3 \%$ & 5 & $31.3 \%$ \\
\hline Total & 3 & $18.8 \%$ & 11 & $68.8 \%$ \\
\hline$\chi 2=8.127 \mathrm{df}=1 \mathrm{p}=0.004$ & 16 & $100 \%$ & 16 & $100 \%$ \\
\hline
\end{tabular}


Change in wet smear and gram stain after sixty days of treatment

In group A, 13 women out of the initial 16 had a normal gram stain and wet smear after 60 days of treatment. In group B, 5 women out of the initial 16 had a normal gram stain and wet smear at the end of treatment. The $\mathrm{p}$ value is 0.004 which is significant (Table 5).

\section{Candidiasis}

In the study, 10 women had vulvovaginal candidiasis. They were randomized to 2 groups A or B, with 5 women in each group. The initial vaginal $\mathrm{pH}$ of all 10 women was normal. All 10 women had an initial wet smear and gram stain suggestive of candidiasis.

Change in Wet smear and gram stain from day 0 to day 30

In group A, 3 out of 5 women had a normal vaginal picture at the end of thirty days of treatment. In the group $\mathrm{B}, 3$ out of 5 women had a normal vaginal picture at the end of thirty days of treatment. The $\mathrm{p}$ value is 1 which is not significant (Table 6).

Table 6: Change in Wet smear and gram stain from day 0 to day 30.

\begin{tabular}{|c|c|c|c|c|}
\hline \multirow{3}{*}{ Change in Wet smear from day 0 to day 30} & \multicolumn{4}{|c|}{ Category } \\
\hline & \multicolumn{2}{|c|}{ Group A } & \multicolumn{2}{|l|}{ Group B } \\
\hline & Frequency & Percent & Frequency & Percent \\
\hline Cured & 3 & $60 \%$ & 3 & $60 \%$ \\
\hline No change & 2 & $40 \%$ & 2 & $40 \%$ \\
\hline Total & 5 & $100 \%$ & 5 & $100 \%$ \\
\hline
\end{tabular}

Change in wet smear and gram stain from day 0 to day 60

In group A, 3 out of 5 women had a normal vaginal picture at the end of sixty days of treatment. In the group $\mathrm{B}, 3$ out of 5 women had a normal vaginal picture at the end of sixty days of treatment. The $\mathrm{p}$ value is 1 which is not significant (Table 7).

\section{Unveiling blinding}

After completion of sample collection and data analysis, the blinding was unveiled. Group A was the probiotics and Group B was the placebo.

Table 7: Change in wet smear and gram stain from day 0 to day 60.

\begin{tabular}{|c|c|c|c|c|}
\hline \multirow{3}{*}{$\begin{array}{l}\text { Change in Wet smear from day } 0 \text { to } \\
\text { day } 60\end{array}$} & \multicolumn{4}{|c|}{ Category } \\
\hline & \multicolumn{2}{|c|}{ Group A } & \multicolumn{2}{|l|}{ Group B } \\
\hline & Frequency & Percent & Frequency & Percent \\
\hline Cured & 3 & $60 \%$ & 3 & $60 \%$ \\
\hline No change & 2 & $40 \%$ & 2 & $40 \%$ \\
\hline Total & 5 & $100 \%$ & 5 & $100 \%$ \\
\hline
\end{tabular}

Table 8: Bacterial Vaginosis - Group A - Probiotic.

\begin{tabular}{|l|l|l|l|l|}
\hline & After 30 days & \multicolumn{3}{c|}{ After 60 days } \\
\hline Change in gram stain from day 0 & Frequency & Percent & Frequency & Percent \\
\hline Normal & 13 & $81.3 \%$ & 13 & $81.3 \%$ \\
\hline Bacterial vaginosis & 3 & $18.8 \%$ & 3 & $18.8 \%$ \\
\hline Total & 16 & $100 \%$ & 16 & $100 \%$ \\
\hline
\end{tabular}


Table 9: Bacterial Vaginosis - Group B - Placebo.

\begin{tabular}{|c|c|c|c|c|}
\hline \multirow[t]{2}{*}{ Change in gram stain } & \multicolumn{2}{|c|}{ After 30 days } & \multicolumn{2}{|c|}{ After $\mathbf{6 0}$ days } \\
\hline & Frequency & Percent & Frequency & Percent \\
\hline Normal & 5 & $31.3 \%$ & 5 & $31.3 \%$ \\
\hline Bacterial vaginosis & 11 & $68.8 \%$ & 11 & $68.8 \%$ \\
\hline Total & 16 & $100 \%$ & 16 & $100 \%$ \\
\hline
\end{tabular}

Table 10: Bacterial Vaginosis - Comparison between probiotic and placebo.

\begin{tabular}{|l|l|l|l|l|}
\hline $\begin{array}{l}\text { Change in gram stain at the end of sixty } \\
\text { days }\end{array}$ & Probiotic & \multicolumn{3}{l|}{ Placebo } \\
\cline { 2 - 5 } Normal & Frequency & Percent & Frequency & Percent \\
\hline Bacterial vaginosis & 13 & $81.3 \%$ & 5 & $31.3 \%$ \\
\hline Total & 3 & $18.8 \%$ & 11 & $68.8 \%$ \\
\hline
\end{tabular}

\section{Bacterial vaginosis}

\section{Group A - Probiotic}

In the case of probiotics, $81.3 \%$ women were cured after 30 days and 60 days of treatment for bacterial vaginosis (Table 8). Group B - Placebo In the case of placebo, $31.3 \%$ women were cured after 30 and 60 days of treatment (Table 9).

Comparison between probiotic and placebo in Bacterial Vaginosis

In the case of probiotics, $81.3 \%$ and in the case of placebo $31.3 \%$ of women were after 30 days and 60 days of treatment for bacterial vaginosis (Table 10).

\section{Candidiasis}

\section{Group A - Probiotic}

At the end of 30 days and 60 days $60 \%$ women with candidiasis were cured in case of probiotic (Table 11). Group B - Placebo At the end of 30 days and 60 days $60 \%$ women with candidiasis were cured in case of placebo (Table 12).

Comparison between probiotic and placebo in candidiasis

The percentage of women cured was $60 \%$ in both probiotic and placebo group. The $\mathrm{p}$ value is 1 which is not significant (Table 13).

Table 11: Candidiasis - Group A - Probiotic.

\begin{tabular}{|l|l|l|l|l|}
\hline \multirow{2}{*}{ Change in Wet smear } & Probiotic & \multicolumn{2}{l|}{ After 60 days } \\
\cline { 2 - 4 } & After 30 days & Frequency & Percent \\
\hline Cured & Frequency & Percent & 3 & $60 \%$ \\
\hline No change & 3 & $60 \%$ & 2 & $40 \%$ \\
\hline Total & 2 & $40 \%$ & 5 & $100 \%$ \\
\hline
\end{tabular}

Table 12: Candidiasis - Group B - Placebo.

\begin{tabular}{|c|c|c|c|c|}
\hline \multirow[t]{3}{*}{ Change in Wet smear } & \multicolumn{4}{|l|}{ Placebo } \\
\hline & \multicolumn{2}{|c|}{ After 30 days } & \multicolumn{2}{|c|}{ After 60 days } \\
\hline & Frequency & Percent & Frequency & Percent \\
\hline Cured & 3 & $60 \%$ & 3 & $60 \%$ \\
\hline No change & 2 & $40 \%$ & 2 & $40 \%$ \\
\hline Total & 5 & $100 \%$ & 5 & $100 \%$ \\
\hline
\end{tabular}


Table 13: Candidiasis - Comparison between probiotic and placebo.

\begin{tabular}{|l|l|l|l|l|}
\hline At the end of sixty days & Probiotic & \multicolumn{3}{l|}{ Placebo } \\
& Frequency & Percent & Frequency & Percent \\
\hline Cured & 3 & $60 \%$ & 3 & $60 \%$ \\
\hline No change & 2 & $40 \%$ & 2 & $40 \%$ \\
\hline Total & 5 & $100 \%$ & 5 & $100 \%$ \\
\hline
\end{tabular}

\section{DISCUSSION}

Lower reproductive tract infections especially the nonsexually transmitted types are quite common in women. They are a cause of morbidity and are associated with significant adverse effects. The present line of management includes the use of antibiotics. However in view of the rising rates of antibiotic resistance, and the fact that these infections tend to recur frequently, has led to a growing interest in the role of natural food supplements, containing friendly bacteria in the management of these conditions. It is known that antibiotics function by killing the pathogens while Lactobacillus GR-1 and RC-14 inhibit the growth and adhesion of urogenital pathogens, displace bacterial vaginosis organisms, down regulate vaginal inflammation and enhance immune defences all of which can make a combined treatment more effective. Under normal circumstances, the person's own lactobacilli would return after antibiotic therapy and colonise the vagina and provide some protection from infection. The additional use of probiotics is considered to enhance this process. The role of probiotics in the management of lower reproductive tract infections has been studied at many centres. Such a study has not been done at our institution, hence the significance of this study.

The present study is a randomised, double blind placebo controlled study. Forty-two women attending the Gynaecology Out-patient Department of Sree Avittom Thirunal Hospital, Thiruvananthapuram, Kerala giving informed consent participated in the study. They were randomised to two groups to receive either of the two drugs $\mathrm{A}$ or $\mathrm{B}$ in addition to the conventional antibiotics. They were followed up for a period of two months to find out if there was any difference in the treatment outcome of both groups. The blinding was unveiled after the data analysis. About one thousand women attended our OPD per month during the study period. Those who satisfied the inclusion criteria were included and those who had the factors of exclusion criteria were excluded. The baseline characteristics of women included in the study was analysed between the two groups and was found to be comparable.

- $50 \%$ of women in the study population were between 26 to 35 years, $35.7 \%$ women were in the age group of 36 to 45 years and $14.2 \%$ women were between 18 to 25 years.
- $\quad 59.5 \%$ women who participated in the study lived in a rural area, while $40.4 \%$ women lived in an urban area.

- $61.9 \%$ women were Hindus, $23.8 \%$ women were Christians and $14.2 \%$ women were Muslims.

- $\quad 71.4 \%$ women in the study group were unemployed while $28.5 \%$ women were employed.

- $\quad 59.5 \%$ had a monthly income less than Rupees 500, $30.9 \%$ women had an income between Rupees 501 to 1600 and $9.5 \%$ women had an income more than Rupees 1601.

- $45.2 \%$ of women in the study population were having an education below 10th standard, while 54.8 $\%$ of women were having an education below 10th standard.

- $\quad 52.3 \%$ of women had their menarche between 14 and 16 years, while $33 \%$ of the women had their menarche before 13 years.

- $80.9 \%$ of the women had regular menstrual cycles, while $19.1 \%$ women had irregular cycles.

- $42.9 \%$ women had taken prior treatment for vaginal discharge.

- $\quad 9 \%$ of women were married less than 5 years, $57 \%$ were married between 5 and 10 years, and $33 \%$ were married more than 11 years.

- $45 \%$ women did not use any form of contraception, 9.5\% used a barrier method, 11. 9\% used an IUCD and $33 \%$ had underwent postpartum sterilisation.

\section{Bacterial vaginosis}

- The initial vaginal $\mathrm{pH}$ at the first visit was alkaline, more than 4.5 for all 32 women.

- The initial wet smear was suggestive of bacterial vaginosis.

- The initial gram stain also showed bacterial vaginosis.

- $\quad$ These 32 women were then randomised to 2 groups A or B. There were 16 women in each group.

- In group A which is the probiotic, from the initial 16 women with an abnormal $\mathrm{pH} ; 13$ women had a normal $\mathrm{pH}$ at the end of thirty days and sixty days of treatment. $(81.3 \%)$

In group B which is the placebo, from the initial 16 women with an abnormal vaginal $\mathrm{pH} ; 5$ women had an normal vaginal $\mathrm{pH}$ at the end of thirty days and sixty days of treatment. (31.3\%). The $\mathrm{p}$ value is 0.004 which is significant. 
In the probiotic group, 13 women out of the initial 16 had a normal gram stain and wet smear after 30 days and 60 days of treatment. In placebo group, 5 women out of the initial 16 had a normal gram stain and wet smear at the end of treatment. The $p$ value is 0.004 which is significant.

\section{Candidiasis}

In the study, 10 women had vulvovaginal candidiasis. They were randomized to 2 groups A or B, with 5 women in each group. The initial vaginal $\mathrm{pH}$ of all 10 women was normal. All 10 women had an initial wet smear and gram stain suggestive of candidiasis.

- In the probiotic group, 3 out of 5 women had a normal vaginal picture at the end of thirty days and sixty days of treatment. (60\%)

- In the placebo group, 3 out of 5 women had a normal vaginal picture at the end of thirty days and sixty days of treatment. $(60 \%)$.

The $\mathrm{p}$ value is 1 which is not significant.

\section{Comparison with other studies}

\section{Bacterial vaginosis}

In Reid et al studied the role of probiotic bacilli containing L. rhamnosus GR-1 and RC-14 alone in maintaining a normal flora in 42 women and found that nearly $64 \%$ women with bacterial vaginosis had a normal urogenital flora at the end of treatment. In their study in, Reid and Charbonneau; 64 healthy women were given daily oral capsules of Lactobacillus rhamnosus GR-1 and RC- 14 for 60 days. Microscopy analysis showed a restoration from an asymptomatic bacterial vaginosis picture to a normal Lactobacilli colonised one in $37 \%$ women as compared to $13 \%$ on placebo $(\mathrm{p}=0.02)$.

In a randomised double blind placebo controlled trial by Anukam et al, oral metronidazole was given along with probiotic capsules to 125 women with bacterial vaginosis for 30 days. They found an improvement in $88 \%$ women in the probiotic group as compared to $40 \%$ in the placebo group $(\mathrm{p}<0.001)$.

In a study by Petricevic and Witt in 2008, 190 women with Bacterial vaginosis were given oral clindamycin along with vaginal Lactobacilli capsules. They found an improvement of $83 \%$ in the probiotic group as compared to $35 \%$ in the placebo group $(\mathrm{p}<0.001)$. Larsson et al in 2008 , gave vaginal clindamycin gel along with vaginal probiotic capsules; and found an improvement of $65 \%$ in the probiotic group as compared to $46 \%$ in the placebo group. In their study in 2005 , Eriksson et al found that clindamycin vaginal cream along with probiotic containing tampons used by 186 women that the improvement in the probiotic group was $56 \%$ as compared to $62 \%$ in the placebo group. (p not specified)
In a study by Bradshaw in 2012, 268 women were given oral metronidazole, vaginal probiotic pessaries and estriol cream and followed up over a period of six months. He found that the improvement in the probiotic group was $73 \%$ as compared to $72 \%$ in the placebo group. When probiotics were used following antibiotic treatment, the bacterial vaginosis cure rate was increased and recurrence rates were reduced in three out of five studies (Anukam et al., 2006; Petricevic and Witt, 2008; Larsson et al., 2008).

In the study conducted at our institution it was found that the cure rate of bacterial vaginosis was $81.3 \%$ at the end of thirty days and sixty days of treatment for probiotics and $31.3 \%$ was the cure rate for placebo at the end of thirty and sixty days of treatment. The $p$ value was 0.004 which was statistically significant.

\section{Vulvovaginal candidiasis}

In 1994, Hilton et al in a prospective cohort study in which 28 women with features of recurrent vulvovaginal candidiasis participated, found that all of them had an improvement of vaginal symptoms. Four of the five women with positive vaginal cultures had negative cultures after receiving lactobacilli. Williams et al in 2001 examined the ability of intravaginally applied lactobacilli to reduce the vulvovaginal candidiasis risk in 164 HIV positive women. The women were randomised to three groups: the first group received L. acidophilus vaginally once per week, the second received vaginal clotrimazole weekly and the third took placebo. The relative risk of developing was 0.5 for the lactobacilli treated, 0.4 for the clotrimazole treated, the difference was not statistically significant.

In 2003, Reid et al administered L. rhamnosus GR-1 and L. fermentum RC-14 in 10 women with recurrent urogenital infections, 9 of them had recurrent yeast vaginitis. One week after the beginning of treatment, lactobacilli dominated the vagina of all women. No recurrences of yeast vaginitis appeared during the study and follow up.

Shalev et al studied 46 women with recurrent candida vaginitis, they were randomised into two groups of 23 women; the first group received $150 \mathrm{ml} /$ day yogurt with lactobacillus and the second group received $150 \mathrm{ml} /$ day of pasteurised yogurt. There was a progressive decrease in positive vaginal cultures for candida for both groups, but it was not significantly different between the two groups.

Pirotta et al did not support the use of lactobacilli for the prevention of post antibiotic vulvovaginitis. The OR for developing post-antibiotic vulvovaginitis was 1.06 in the study group and 1.38 in the placebo group which was not statistically significant. In the study conducted at our institution, it was found that the cure rate for candidiasis was $60 \%$ for probiotics, and $60 \%$ for placebo. The $p$ value was 1 which was not statistically significant. 


\section{Limitations}

There are several limitations in this study. As the cost of the medicines were high and the sample size was not extensive, we could not find out if the difference in the probiotic and placebo group outcome could have been more significant. Also the women were followed up only for a period of 2 months. Their chance of developing recurrent infections over a longer period of time was not studied.

\section{CONCLUSION}

In the treatment of bacterial vaginosis, addition of probiotics to the conventional antibiotics can improve the cure rate of bacterial vaginosis and reduce the rate of recurrences. In the treatment of vulvovaginal candidiasis, addition of probiotics to the conventional antifungal did not have a significant improvement.

\section{ACKNOWLEDGEMENTS}

Authors would like to thank Mr. Babu and $\mathrm{Mr}$. Jayakumar, Statisticians, Government Medical College, Thiruvananthapuram for carrying out the statistical analysis of this study and guiding them for the final outcome of this study. Authors would also like to thank $\mathrm{M} / \mathrm{s}$ Tablets India, for providing us valuable assistance for the completion of this study. Authors sincere gratitude is to all present patients and their families for having cooperated in our study. Thanks to GOD Almighty for giving us all strength and blessings to complete our work successfully.

\section{Funding: No funding sources}

Conflict of interest: None declared

Ethical approval: The study was approved by the Institutional Ethics Committee

\section{REFERENCES}

1. Wilson M. Bacterial biofilms and human disease. Science progress. 2001;84:235-54.

2. Savage DC. Microbial ecology of the gastrointestinal tract. Annu Rev Microbiol. 1977;31:107-33.

3. Costerton JW, Irwin RT, Cheng KJ. The bacterial glycocalyx in nature and disease. Annu Rev Microbiol. 1981;35:399-424.

4. Chan RCY, Bruce AW, Reid G. Adherence of cervical, vaginal and distal urethral normal microbial flora to human uroepithelial cells and the inhibition of adherence of uropathogens by competitive exclusion. J Urol. 1984;131:596-601.

5. Lamont RF, Sobel JD, Akins RA, Hassan SS, Chaiworapongsa T, Kusanovic JP, Romero R. The vaginal microbiome: new information about genital tract flora using molecular based techniques. BJOG. 2011; 118: 533-549.

6. Vasquez A, Jakobsson T, Ahrne S, Forsum U, Molin G. Vaginal Lactobacillus Flora of Healthy Swedish
Women. Journal of Clinical Microbiology. 2002;40(8):2746-9.

7. Barbes BC. Role played by lactobacilli in controlling the population of vaginal pathogens. Microb. Infect. 2000;2:543-6.

8. Soper E, Berek S. Berek and Novak Gynaecology. 2007.

9. Galask RP. Vaginal colonization by bacteria and yeast. Am J Obstet Gynecol. 1988;158:993-5.

10. Aroutcheva A, Gariti D, Simon M, Shott S, Faro J, et al. Defense factors of vaginal lactobacilli. Am J Obstet Gynecol. 2001;185:375-9.

11. Bayer AS, Chow AW, Concepcion N, Guze LB. Susceptibility of 40 lactobacilli to six antimicrobial agents with broad gram-positive anaerobic spectra. Antimicrob Agents Chemother. 1978;14:720-2.

12. Gardner HL, Dukes CD. Haemophilus vaginalis vaginitis: a newly defined specific infection previously classified "non-specific" vaginitis. Am J Obstet Gynecol. 1955;69:962-76.

13. Fredricks DN, Fiedler TL, Marrazzo JM. Molecular identification of bacteria associated with bacterial vaginosis. N. Engl. J. Med. 2005;353;1899-911.

14. Amsel R, Totten PA, Spiegel CA, Chen KCS, Eschenbach D, Holmes KK. Nonspecific vaginitis. Diagnostic criteria and microbial and epidemiologic associations. Am J Med. 1983;74:14-22.

15. Hillier SL. Diagnostic microbiology of bacterial vaginosis. Am J Obstet Gynecol. 1993;169:455-9.

16. Oommen Rebecca; Study on prevalence of bacterial vaginosis in women attending gynaecology OPD of SATH. 2009.

17. Taylor RD, McCaffrey M, Pitkin J, Lamont RF. Bacterial vaginosis in climacteric and menopausal women. Int. J. STDs AIDS. 2002;13:449-52.

18. Easmon CS, Hay PE, Ison CA. Bacterial vaginosis: a diagnostic approach. Genitourin Med. 1992;68:1348.

19. Cook RL, Redondo-Lopez V, Schmitt C. Clinical, microbiological and biochemical factors in recurrent bacterial vaginosis. J Clin Microbiol. 1992;30;870-7.

20. Wiesenfeld H, Hillier S, Krohn MA, Landers D. Bacterial vaginosis is a strong predictor of Neisseria gonorrhoeae and Chlamydia trachomatis infection. Clin Infect Dis. 2005;36:663-8.

21. Koumans EM, Markowitz LE, Hogan V. Indications for therapy and treatment recommendations for bacterial vaginosis in non-pregnant and pregnant women: a synthesis of data. Clin Infect Dis. 2002;35 (Suppl. 2):152-72.

22. Wiesenfeld HC, Peipert J, Soper D, Ohmit SE, Hillier SL. Suppressive antibacterial therapy with $0.75 \%$ metronidazole vaginal gel to prevent recurrent bacterial vaginosis. Am J Obstet Gynecol. 2002;194;1283-9.

23. Eckert LO, Moore DE, Patton DL, Agnew KJ, Eschenbach DA. Relationship of vaginal bacteria and inflammation with conception and early pregnancy loss following in-vitro fertilization. Infect Dis Obstet Gynecol. 2003;11:11-7. 
24. Klebanoffm A, Schwebke JR, Zhang J, Nansel TR, $\mathrm{Yu} \mathrm{KF}$, Andrews W. Vulvovaginal symptoms in women with bacterial vaginosis. Obstet Gynecol. 2002; 104:267-72.

25. Nugent RP, Krohn MA, Hillier SL. Reliability of diagnosing bacterial vaginosis is improved by a standardized method of gram stain interpretation. J Clin Microbiol. 1992;29:297-301.

26. Suvarna VC, Boby VU. Probiotics in human health: A current assessment. Current science. 2005;88:1744-48.

27. Reid G, Beuerman D, Heinemann C, Bruce AW. Probiotic Lactobacillus dose required to restore and maintain a normal vaginal flora. FEMS Immuno Med Microbiol. 2001;32:37-41.

28. Bruce N, Fraser C, Heinemann, Owen J, Henning B. Oral probiotics can resolve urogenital infections. FEMS Immunol. Med. Microbiol. 2001;30:49-52.

29. Gregor R, Jass J, McCormick JK. Potential Uses of Probiotics in Clinical Practice. Clin Microbiol Rev. 2003; 16:658-72.

30. Barrons R, Tassone D. Use of Lactobacillus probiotics for bacterial genitourinary infections in women: a review. Clin Ther. 2008;30:453-68.

31. Borchers AT, Selmi C, Meyers FJ, Keen CL, Gershwinm E. Probiotics and immunity. J Gastroenterol. 2009;44:26-46.

32. Mastromarino $\mathrm{P}$, Brigidi $\mathrm{P}$, Macchia $\mathrm{S}$. Characterization and selection of vaginal Lactobacillus strains for the preparation of vaginal tablets. J Appl Microbiol. 2002;93:884-93.

33. Bradshaw CS, Morton AN, Hocking J. High recurrence rates of bacterial vaginosis over the course of 12 months after oral metronidazole therapy and factors associated with recurrence. J Infect Dis. 2006;193:1478-86.
34. Reid GD, Charbonneau JE, Kochanowski B, Beuerman D, Poehner R, Bruce AW. Oral use of Lactobacillus rhamnosus GR-1 and L. fermentum RC-14 significantly alters vaginal flora: randomized, placebo-controlled trial in 64 healthy women. FEMS Immunol. Med. Microbiol. 2003;35:131-4.

35. Reid G, Charbonneau D, Gonzalez S, Gardiner G, Erb J, Bruce AW. Ability of Lactobacillus GR-1 and $\mathrm{RC}-14$ to stimulate host defences and reduce gut translocation and infectivity of Salmonella typhimurium. Nutraceut Food. 2002;7:168-73.

36. Reid G, Bruce AW, Fraser N, Heinemann C, Owen J, Henning B. Oral probiotics can resolve urogenital infections. FEMS Immunol Med. Microbiol. 2001:30;49-52.

37. Anukam KC, Osazuwa E, Osemene GI, Ehigiagbe F, Bruce AW, Reid G. Clinical study comparing probiotic Lactobacillus GR-1 and RC-14 with metronidazole vaginal gel to treat symptomatic bacterial vaginosis. Microbes Infect. 2006;8:2772-6.

38. Anukam K, Osazuwa E, Ahonkhai I, Osemene G, Bruce AW, Reid G. Augmentation of antimicrobial metronidazole therapy of bacterial vaginosis with oral probiotic Lactobacillus rhamnosus $\mathrm{gR}-1$ and Lactobacillus reuteri RC-14: randomized, doubleblind, placebocontrolled trial. Microbes Infect. 2006;8:1450-4

39. Williams $\mathrm{AB}, \mathrm{Yu} \mathrm{C}$, Tashima K. Evaluation of two self-care treatments for prevention of vaginal candidiasis in women with HIV.J Assoc Nurses AIDS Care. 2001;12:51-7.

Cite this article as: Shamshu R, Vaman J, Nirmala C. Role of probiotics in lower reproductive tract infection in women of age group 18 to 45 years. Int $\mathbf{J}$ Reprod Contracept Obstet Gynecol 2017;6:671-81. 